O.S. Kolesnyk, doctor of philology, professor

Kyiv Borys Grinchenko University

\title{
EXISTENTIAL PHENOMENA IN LANGUAGE AND MYTHIC SPACE
}

The article considers verbal representations of existential phenomena from the standpoint of universalia-centered linguistics and the methodology of M-logic. Special attention is paid to the etymological analysis of the LIFE concept's names in Indo-European languages and the reconstruction of the cognitive models, the latter being the bases of the lingual units designating the said phenomena in the archaic Germanic languages.

Key words: existential phenomenon, mythic space, semantics, sense, model

\section{А.С. Колесник, доктор филологических наук, профессор} Киевский университет имени Бориса Гринченко

\section{ЭКЗИСТЕНЦИАЛЬНЫЕ ФЕНОМЕНЫ В ЯЗЫКЕ И МИФОЛОГИЧЕСКОМ ПРОСТРАНСТВЕ}

В статье анализируются вербальные репрезентации экзистенциальных феноменов с позиций лингвоунсверсологии и М-логики. Главное внимание уделяется анализу этимологии имен концепта ЖИЗНЬ в индоевропейских языках, и реконструкиии когнитивных моделей, составляющих основу номинаций указанных явлений в архаических германских языках.

Ключевье слова: экзистенциальный феномен, мифологическое пространство, семантика, смысл, модель.

УДК $81^{\prime} 42$

Кравченко Н. Г., к. філол. Н.,

Центр наукових досліджень та викладання іноземних мов НАН України, м.Київ

\section{СИНЕРГЕТИКА ДИСКУРСУ У МІЖКУЛЬТУРНОМУ КОНТЕКСТІ}

Розвиток мовознавчих досліджень в умовах глобалізачиї набуває нового осмислення, оскільки корелює з культурологією, етнологією, а також експлікується з лінгвокультурним надбанням. Сучасні лінгвістичні розвідки екстрапольовані на проблеми міжкультурної комунікації, лінгвоестетики, вивчення національно-культурних реалій. 
Розгляд мов, зокрема германських, у міжкультурній взаємодії виявляється актуалізованим, тому щзо знання національних цінностей $i$ особливостей спілкування носіїв германських мов сприяють розумінню специифіки пізнання їхнього культурного середовищча.

Ключові слова: міжкультурний вимір, синергетична парадигма, дискурс, внутрішнє мовлення, внутрішній монолог.

Синергетична парадигма дозволяє системно усвідомлювати основні тенденції лінгвокультурних реалій певної спільноти, а також вивчати еволюційні процеси культурного надбання у контексті світового масштабу. Синергетичний підхід передбачає залучення соціологічного аспекту задля розуміння природи явищ, пов’язаних із системною організацією і динамікою перетворення хаосу та неорганізованості на гармонію та порядок. Ці процеси характерні і для лінгвістичної науки, для мовних і мовленнєвих явищ, яким властиві як статичність, так i динамічність, а також лінгвальні й екстралінгвальні аспекти.

Дослідники у галузі соціальних знань неодноразово обгрунтовували перспективність застосування теорій хаосу та інших синергетичних концепцій у дослідженнях різних наук. Було констатовано зростання темпів змін соціально-економічних $\mathrm{i}$ політичних процесів як невизначених та хаотичних явищ, котрі зумовлюють неочікувані результати. При цьому науковці наголошують на подібності векторів розвитку соціальногуманітарних та природничих систем. Таким чином, актуальною постає інтеграція синергетичного підходу до вивчення різноманітних проблем, зокрема і в мовознавчих студіях.

Доречно зазначити позиції лінгвістів Л. С. Піхтовнікової та Р.Г. Піотровського, котрі акцентували увагу на перспективності синергетичного підходу до вивчення мовних та мовленнєвих процесів. Зокрема, Л.С. Піхтовнікова стверджує, що синергетична парадигма має 
надзвичайну наукоємність, в той час як іiі впровадження у лінгвістику $є$ прогресивним [4, с. 22]. 3 іншого боку, Р. Г. Піотровський вважає, що вирішення лінгвістичних завдань потребує кардинально нових технологій, експлікованих міждисциплінарністю. У такий спосіб, синергетичний аспект у мовознавстві демонструє широкий діапазон новітніх засобів дослідження, відмінних від консервативних. Характерно, що поняттєвий апарат синергетики сприяє модернізованому підходу при розгляді синергетичної природи дискурсу, зокрема і в міжкультурній взаємодії [1, с. 98-99].

Синергетика уможливлює актуалізоване вивчення лінгвістичних проблем у кореляції з соціально-історичними факторами - визначальними чинниками у процесі формування міжкультурних відношень. Водночас освіта та культурне середовище впливають на формування індивідуального стилю та інтенції авторів, відображених на рівні дискурсу. Вочевидь, вираження індивідуальної авторської стратегії реалізується за допомогою певного художнього методу, вплив на який мають не тільки особистісні характеристики автора, але й культурні та соціальні фактори.

У результаті, виокремлюється авторська модель 3 індивідуальними мовленнєвими інтенціями, яка відбивається у площині дискурсу. Передусім авторський стиль характеризується наявністю певних лексичних, лексикограматичних, синтаксичних стилістичних засобів, за допомогою яких відображається творчий задум автора [3, с. 7]. При цьому кожен автор увиразнюється особистісним форматом, в якому реалізуються його художні уявлення, особистісний психотип, індивідуальні принципи і концепції, ціннісні орієнтири, детерміновані культурними, соціальними та іншими чинниками. Такий процес, безперечно, корелює не тільки з національним, але і з міжкультурним надбанням, коли автор інтегрується в інші лінгвокультурні реалії та збагачує себе етнокультурним аспектом світового рівня. Проте кожний автор характеризується певним ідіостилем, котрий сигналізує його 
неповторність.

Доречно відзначити, що і для відповідної літературної епохи випадає свій хронологічно означений час, у якому домінують «специфічні» культурно-стильові характеристики [7, с. 179]. Вони еволюціонують і набувають домінантних ознак, але під тиском нових культурно-стильових тенденцій та естетичних ідеалів, літературних течій і суспільно-політичних чинників трансформуються чи взагалі зникають. Проте між літературними, а також культурно-історичними періодами існує зв'язок, який презентує цілісність мовного і мовленнєвого здобутку окремої лінгвокультурної спільноти, що, власне, є складовою літературного процесу на рівні світового масштабу [2, с. 54].

Відповідно до синергетичної парадигми, синергія дискурсу корелює 3 певним базовим інструментарієм. Так, з позиції синергетики, дискурс - це лінгвістичний об’єкт, здатний до самоорганізації, функціонування якого реалізується у площині синергетичної системи.

Синергетична система - це відкрита адаптивна система, здатна до самоорганізації, що складається із множини складних динамічних підсистем під управлінням параметра порядку. Відомо, що система, яка еволюціонує самостійно, має бути відкритою i дисипативною. Ці характеристики забезпечують обмін інформацією між системою та навколишнім світом. До того ж, саме такий обмін підтримує існування та функціонування системи [6, с. 23].

Синергетика досліджує принципи самоорганізації системи, котрі здатні еволюціонувати та адекватно реагувати на зовнішні фактори. При цьому вони змінюють відповідні характеристики, структуру, функції, що забезпечує ефект самозбереження. Такі процеси властиві i для дискурсу, який скоординований організаційним змістом і еволюцією системи знань та їх передачею при формуванні процесу комунікації [5, с. 134]. 
Відповідно до синергетичної парадигми, автор є як творчим інженером дискурсу, так і засобом атракторів та репелерів цього дискурсу. Саме у такому сенсі ми трактуємо самоорганізацію дискурсу, під час якої констатуємо конкурентну взаємодію змістів атрактора та репелера. Цілі утворення дискурсу та такі засоби їх здійснення, як композиція та стратегії побудови, сукупність дійових осіб та сюжетів дискурсу, становлять зміст атрактора. Атрактор виступає вектором формування дискурсу у певному напрямку, а його опонентом $є$ репелер, котрий містить обмеження на утворення дискурсу: обсяг тексту, очікування суб’єктів дискурсу, а також традиції жанру. Рух до спільної мети - створення дискурсу - атрактор і репелер здійснюють протилежними шляхами: зміст репелера відповідає за формування стійкої форми дискурсу (зміст відповідно до жанрових традицій, архітектоніку та прийнятний обсяг), в той же час зміст атрактора надає формі та змісту динаміку і гнучкість, що забезпечує втілення творчого задуму автора [5, c. 135].

У результаті, цікавим видається розгляд внутрішньомовленнєвої діяльності персонажа на тлі дискурсу 3 позиції синергетики. Так, внутрішньмовленнєвий процес презентує інтерактивну взаємодію культурних та особистісних характеристик автора, відбитих у внутрішній комунікації персонажа-оповідача - суб’єкта «Я». Звісно, внутрішньомовленнєва форма вербалізації персонажа відтворюється автором на основі його творчого задуму у кореляції 3 особистісним світоглядом, культурними й міжкультурними аспектами, емоційним та психологічним станом, що реалізується ним на рівні дискурсу у формі атрактора.

3 позиції синергетики, конкуренція атрактора й репелера (обмеження при створені дискурсу) обумовлює підгрунтя для самоорганізації дискурсу. Водночас конкуренція зумовлює поляризацію, при якій сигналізуються протилежні властивості атрактора й репелера. При цьому автор бере до уваги 
різновекторні характеристики атрактора i репелера та продукує власний консенсус.

Таким чином, внутрішньомовленнєва діяльність, зокрема внутрішній монолог, відтворює конвенціональні психічні i когнітивні параметри представників певного лінгвокультурного виміру. Цей процес має не тільки національні параметри, а й взаємодіє із різними культурами.

У результаті, автор втілює у формування дискурсу лінгвокультурні коди міжкультурного простору. До того ж, автор синхронно репрезентує роль атрактора i репелера - головних складових при вибудовуванні та функціонуванні дискурсу.

Отже, синергетична парадигма при розгляді синергії дискурсу виокремлює генерування лінгвальних і екстралінгвальних аспектів певної лінгвокультурної спільноти й увиразнює їі особливості на тлі міжкультурної взаємодії.

\section{СПИСОК ВИКОРИСТАНИХ ДЖЕРЕЛ}

1. Домброван Т.И. Синергетическая модель развития английского языка. Монография /Татьяна Ивановна Домброван. - Одесса: КП ОГТ, 2014. - 400 с. 2. Кравченко Н. Г. Афективне внутрішнє мовлення в німецькомовній художній прозі $\mathrm{XX}$ століття: дис.... канд. філол. наук: спец. 10.02 .02 «Германські мови» / Кравченко Наталія Григорівна. - К., 2016. - 227 с. 3. Кравченко Н.Г. Афективне внутрішнє мовлення в німецькомовній художній прозі XX століття: автореф. дис. на здобуття наук. ступеня к. філол. наук: спец. 10.02.04 «Германські мови» / Наталія Григорівна Кравченко. Запоріжжя., 2016. - 20 с. 4. Пихтовникова Л. С. Лингвосинергетика: основы и очерк направлений: монография / Лидия Сергеевна Пихтовникова. - Х.: ХНУ имени В. Н. Каразина, 2012. - 180 с. 5. Піхтовнікова Л. С. Прагмастилістичні характеристики німецькомовної притчі: монографія / Л. С. Піхтовнікова, І. М. Яремчук. - Х.: ХНУ імені В. Н. Каразіна, 2017. - 220 с. 6. Піхтовнікова Л. С. Синергія стилю байки: німецька віршована байка 13-20 ст.: монографія / Лідія Сергіївна Піхтовнікова. - Харків: Бізнес Інформ, 1999. - 220 с. 7. Arbeitsbuch: Literaturwissenschaft / [Hg., Thomas Eicher, Volker 
Wiemann]. - [3. Auflage]. - Paderborn, München, Wien, Zürich: Schöningh, 2001.- 226 s.

Стаття надійшла до редакції 30.08.2018.

\section{Kravchenko N. H., Cand.Phil.Sci., Assistant Professor, Research and Educational Center of Foreign Languages of the National Academy of Sciences of Ukraine, Kyiv city DISCOURSE SYNERGY IN THE INTERCULTURAL CONTEXT}

The development of linguistic research in the conditions of globalization acquires a new understanding, since it correlates with culturology, ethnology, and explicates the linguistic and cultural heritage. Modern linguistic intelligence is extrapolated to the problems of intercultural communication, linguistic aesthetics, and the study of national and cultural realities. The consideration of languages, in particular Germanic, in intercultural interaction appears to be actualized, because the knowledge of national values and communication peculiarities of Germanic native speakers contributes to the comprehension of the specific cognition nature of their cultural environment.

Key words: intercultural dimension, synergetic paradigm, discourse, inner speech, inner monologue.

Кравченко Н. Г., канд. филол. н., Центр научных исследований и преподавания иностранных языков НАН Украины, 2.Kues

\section{СИНЕРГЕТИКА ДИСКУРСА В МЕЖКУЛЬТУРНОМ КОНТЕКСТЕ}

Развитие языковедческих исследований в условиях глобализачии приобретает новое осмысление, поскольку коррелирует с культурологией, этнологией, а также эксплицируется с лингвокультурным достоянием. Современные лингвистические разведки экстраполированы на проблемь межкультурной коммуникации, лингвоэстетики, а также на изучение национально-культурных реалий. Рассмотрение языков, в частности германских, в межкультурном взаимодействии является актуализированным, так как знания национальных иенностей и особенностей общения носителей германских языков способствуют пониманию специфики познания их культурной среды.

Ключевые слова: межкультурное измерение, синергетическая парадигма, дискурс, 
внутренняя речь, внутренний монолог.

УДК 811.112.2'25

Кучма O.І., к. філол. н., доц.

Інститут філології КНУ імені Тараса Шевченка,м. Київ

\section{ФОРМУВАННЯ НАВИЧОК ПЕРЕКЛАДУ НАУКОВО-ТЕХНІЧНИХ ТЕКСТІВ: ДОСВІД ТА ПЕРСПЕКТИВИ}

В статті узагальнюється досвід перекладу різних типів науково-технічних (фахових) текстів з німецької мови на українську та викладання практичного курсу перекладу цих текстів. Аналізуються проблеми, пов'язані з перекладом фахових текстів українською мовою, які мають бути враховані в прочесі підготовки перекладачів.

Ключові слова: науково-технічні тексти, калька, псевдотермін, граматичні проблеми.

Протягом останніх десятиліть науково-технічні тексти як носії передових наукових та технічних знань перекладаються чи не найчастіше у всьому світі [2: 191], а тому зростає потреба у кваліфікованих перекладачах такої літератури. Відповіддю на суспільний запит стало включення до університетських навчальних планів з підготовки перекладачів таких курсів, як переклад юридичних, науково-технічних, фінансово-економічних текстів, ділового мовлення. Наявні електронні перекладачі (забезпечуючи швидкість, але не якість перекладу) не повністю задовольняють потреби замовників, зокрема щодо прагматичних та культурних адаптацій тексту перекладу, а тому машинний переклад потребує втручання людини, в ідеалі, власне, двох осіб: перекладача і фахівця відповідної галузі (pre-editing, post-editing). Це мають бути в першу чергу спеціалісти зі знанням відповідних мов та технік перекладу, гнучкою здатністю до опанування термінології в певній галузі 